\title{
Improving Adaptive Learning Rate With Backpropogation on Retail Rice Price Prediction in Traditional Markets
}

\author{
Erwin Binsar Hamonangan Ompusunggu ${ }^{1}$, Solikhun ${ }^{2}$, Iin Parlina ${ }^{3}$, Sumarno $^{4}$, \\ Indra Gunawan ${ }^{5}$ \\ 1,4,5STIKOM Tunas Bangsa, Pematangsiantar, North Sumatra, Indonesia \\ ${ }^{2,3}$ AMIK Tunas Bangsa, Pematangsiantar, North Sumatra, Indonesia \\ erwinbinsar1992@gmail.com
}

\begin{abstract}
Rice is the most important staple food and carbohydrate food in the world especially people in Indonesia. This study aims to predict the retail price of rice in traditional markets using backpropogation by improvising Adaptive Learning Rate to increase the value of accuracy. Data sources were obtained from the Central Statistics Agency (BPS) in 33 provinces in Indonesia for the retail price of rice in the traditional market (Rupiah / $\mathrm{kg})$ for the past 6 years (2011-2016). The results of the study state that the improvised learning rate uses 2 models: $2-10-1$ and $2-15-1 \quad(L R=0,1 ; 0,5 ; 0,9)$ that the best architectural models are 4-15-1 $(L R=0.9)$ with an accuracy of $82 \%$, Training MSE 0,000999936, Testing MSE 0.016051433 and Epoch 20515. The results of this study are expected to provide input to the government in providing input on predictions of retail rice prices that have an impact on the stability of rice prices in Indonesia.
\end{abstract}

Keywords: Learning rate, Improvisation, Prediction, Rice Prices, Backpropogation.

\section{Introduction}

Rice is a food source of carbohydrates and the most important staple food in the world. This is true in Asia where rice is the staple food for the majority of the population and is home to farmers who produce around $90 \%$ of total world rice production. For the people of Indonesia consuming rice is a basic need so that Indonesia is recorded as the country with the highest rice consumption in the world. Based on FAOSTAT December 2014 data sources, the country of Indonesia is one of the countries in Asia as the largest rice producing country in the world.

Table 1. The Largest Rice Producer in Asia
\begin{tabular}{|l|r|}
\hline Country & Production Volume \\
\hline China & $208,100,000$ \\
\hline India & $155,500,000$ \\
\hline Indonesia & $70,600,000$ \\
\hline Bangladesh & $52,400,000$ \\
\hline Vietnamese & $44,900,000$ \\
\hline World & $\mathbf{7 4 1 , 5 0 0 , 0 0 0}$ \\
\hline
\end{tabular}

Even though Indonesia is one of the biggest rice producing countries in the world, Indonesia still needs to import rice almost every year. This situation is caused by farmers using sub-optimal farming techniques coupled with large per capita rice consumption. Indonesia is also one of the largest per capita rice consumption in the entire world where Indonesians spend more than half of their total expenditure on food ingredients. Therefore the government must regulate the distribution process and maintain the stability of rice prices in Indonesia. Based on the above problems it is necessary to conduct a study related to predictions. Many 
branches of computer science discuss prediction problems such as Datamining [1][5] and Artificial Neural Networks [6]-[9].

Artificial Neural Networks (ANN) is a network consisting of a group of small processing units that are inspired by the human biological nerve cell system modeled based on human neural networks [10], [11]. ANN has the advantage to solve a problem that has the same pattern as the example given so ANN can be used to solve problems that are discrete, real or vector [10]. One algorithm used to make predictions with Artificial Neural Networks is Backpropogation. Backpropogation has the advantage that one of them is to use 2 grooves in weight calculation, namely forward propagation and back propagation [12]. In addition Backpropagation also trains the network to get a balance between the ability of the network to recognize patterns used during training and the ability of networks to provide correct responses to patterns of input that are similar (but not the same) to the patterns used during training [10]. Many studies related to backpropogation conducted by researchers about prediction. One of them is research [13] on State Retail Sukuk. In that study, it was explained that the Backpropogation Algorithm was able to predict the most investors in the purchase of the State Retail Sukuk. Input variables used are Civil Servants (X1), Private Employees (X2), IRT (X3), Entrepreneurs (X4), TNI / Police (X5) and Others (X6) with 4 architectural training and testing models namely 6-2-1, 6-5-1,6-2-5-1 and 6-5-2-1. The best architectural models in the study are 6-52-1 with epoch 37535, MSE 0,0009997295 and 100\% accuracy. The sensitivity analysis will be done from this model to see which variable has the best performance and obtained the Private Employee (X2) variable with a score of 0.3268. In order to get the most investor prediction results on the purchase of sukuk for the next 008 series based on the profession category are Private Employees. From the description above, it is hoped that this rese arch can predict the Retail Price of Rice in traditional markets by improvising the Adaptive Learning Rate to increase the prediction accuracy value. We know that the prediction accuracy done by previous researchers is purely using the Backpropogation method. The result of the prediction accuracy is the percent level $(\%)$. The higher the level of percent $(100 \%)$ obtained, the better the architecture model is made and vice versa the lower the level of percent (50\%) obtained, the worse the architectural model is made. In this case the researchers used improvised Adaptive Learning Rate to predict the retail price of rice in traditional markets using backpropogation. so the results obtained are more leverage to increase the predictive value of previous researchers who did not use Adaptive Learning Rate improvisation. For the government, it is hoped that this research can be useful in providing input on retail rice price predictions that have an impact on rice price stability in Indonesia.

\section{Research Methodology}

\subsection{Artificial intelligence}

Artificial Intelligence is the largest contribution in the field of AI, which was preceded by an article from Alan Turing in 1950 entitled Computing Machinery and Intelligence discussing the terms of a machine is considered intelligent [14].

\subsection{Artificial Neural Networks}

Artificial neural network (ANN) is a network consisting of a group of small processing units that are modeled based on human neural networks that are created as a generalization of mathematical models of human understanding [15].

\subsection{Backpropagation Method}

Backpropagation model is a supervised leaning technique that is most widely used in dealing with the problem of recognizing complex patterns. Improvised Adaptive Learning Rate is a spontaneous action with a method that aims to increase 
the effectiveness of learning level parameters that serve to increase the speed of learning from backpropagation [6], [7].

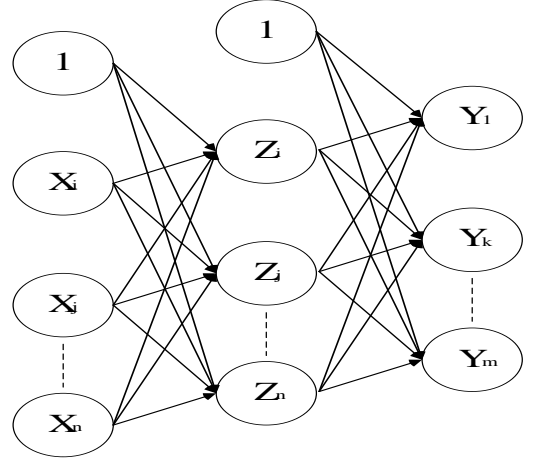

Figure 1. Backpropagation Network Architecture

Research methodology is the stage of conducting research in collecting data or information used in finding solutions to problems as shown in the following flowchat.

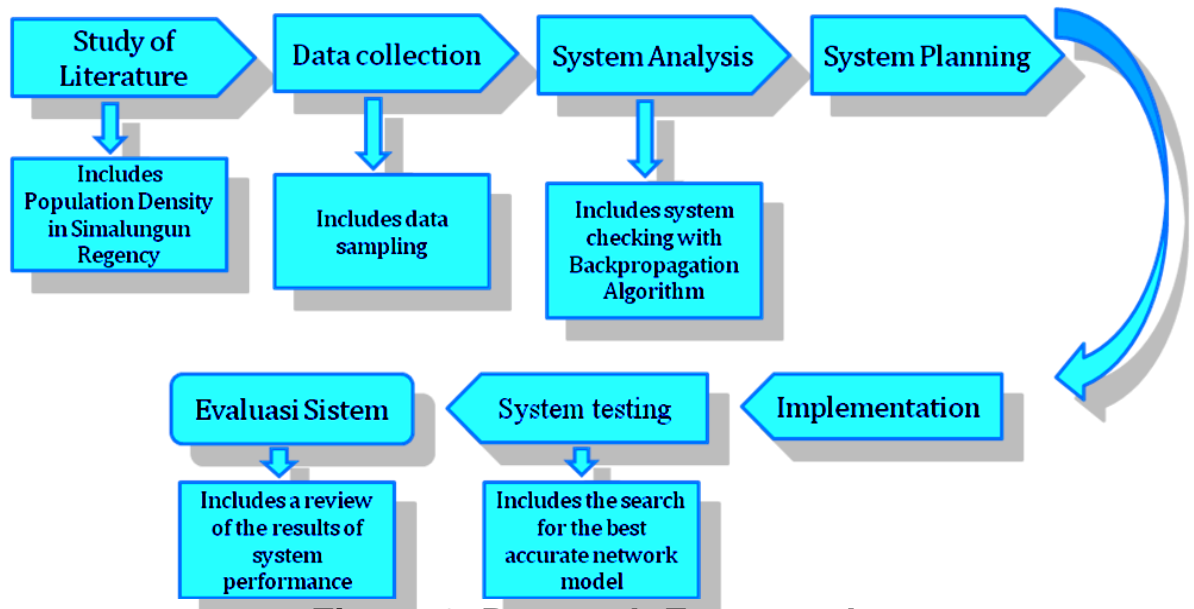

Figure 2. Research Framework

\subsection{Data source}

The process of using the backpropogation method has two stages where the first stage is pattern recognition by finding the best architecture of the artificial neural network model that is made. The process of training and testing data to get the best model obtained from the Badan Pusat Statistic (BPS) in 33 provinces in Indonesia for the retail price of rice in traditional markets (Rupiah/Kg) for the last 6 years (2011-2016). The second stage is to make predictions with the best architectural patterns obtained in the first stage. The testing process is carried out by entering research data by comparing the minimum error values obtained from the best architectural patterns performed in the first stage.

Table 1. Data on average retail prices of rice in traditional markets

\begin{tabular}{|l|r|r|r|r|r|r|}
\hline \multirow{2}{*}{ City Retail Price } & \multicolumn{6}{|c|}{ Average Retail Price of Rice in Traditional Markets in 33 Cities (Rupiah/Kg) } \\
\cline { 2 - 7 } & \multicolumn{1}{|c|}{2011} & \multicolumn{1}{c|}{2012} & 2013 & \multicolumn{1}{|c|}{2014} & 2015 & \multicolumn{1}{c|}{2016} \\
\hline Banda Aceh & 8247.31 & 8606.16 & 9075.62 & 9330.47 & 9735.41 & 10244.09 \\
\hline Medan & 7725.61 & 8601.97 & 9171.82 & 9574.73 & 10146.74 & 10547.87 \\
\hline Padang & 9878.17 & 9620.26 & 9558.50 & 11712.50 & 12258.02 & 12789.53 \\
\hline Pekanbaru & 9600.82 & 9601.14 & 9886.08 & 11171.72 & 11711.67 & 12270.42 \\
\hline Tanjung Pinang & 8031.48 & 9786.41 & 10321.85 & 11365.26 & 12424.87 & 10573.25 \\
\hline Jambi & 7631.13 & 8710 & 9159.88 & 9683.54 & 10335.91 & 9644.11 \\
\hline Palembang & 7643.67 & 8407.40 & 8676.74 & 8876.55 & 9644.30 & 10370.57 \\
\hline
\end{tabular}




\begin{tabular}{|l|r|r|r|r|r|r|}
\hline Pangkal Pinang & 7667.32 & 8898.21 & 9291.09 & 9528.82 & 10751.58 & 9966.58 \\
\hline Bengkulu & 7556.16 & 8116.50 & 8401.98 & 9696.08 & 10419.91 & 11416.46 \\
\hline Bandar Lampung & 10574.74 & 8754.79 & 8974.06 & 9817.36 & 1020.47 & 13767.38 \\
\hline Jakarta & 9929.83 & 9037.23 & 9447.22 & 10027.05 & 11732.98 & 12413.75 \\
\hline Bandung & 7639.10 & 8405.67 & 8571.61 & 9018.31 & 10695.56 & 11231.04 \\
\hline Serang & 7761.37 & 7708.31 & 7931.05 & 8151.26 & 9151.21 & 10379.40 \\
\hline Semarang & 7183.22 & 8398.18 & 8791.97 & 9187.41 & 9902.22 & 9872.40 \\
\hline Yogyakarta & 7798.90 & 7902.48 & 8383.10 & 9062.10 & 9771.84 & 10249.07 \\
\hline Surabaya & 6493.79 & 8335.03 & 8794.77 & 9209.61 & 10132.20 & 9553.36 \\
\hline Denpasar & 8332.57 & 8647.23 & 9044.05 & 9315.86 & 10378.28 & 10580.99 \\
\hline Mataram & 6609.87 & 7704.52 & 7776.14 & 8576.47 & 9608 & 9720.53 \\
\hline Kupang & 8058.16 & 8435.67 & 8921.70 & 9127.71 & 9999.64 & 11084.87 \\
\hline Pontianak & 9116.78 & 9828.72 & 10326.79 & 10814.36 & 12012.61 & 12477.20 \\
\hline Palangkaraya & 10882.96 & 11006.28 & 10742.08 & 12421.42 & 14727.73 & 13813.61 \\
\hline Banjarmasin & 9343.89 & 10127.24 & 9960.22 & 11272.31 & 12533.07 & 12910.90 \\
\hline Samarinda & 8056.50 & 9053.94 & 9563.21 & 11088.35 & 11429.31 & 11248.34 \\
\hline Manado & 7677.71 & 8706.13 & 8901.29 & 9223.42 & 10470.17 & 11665.84 \\
\hline Gorontalo & 7014.97 & 8237.56 & 8398 & 8620.03 & 9362.14 & 10358.26 \\
\hline Palu & 6503.52 & 7958.49 & 7949.16 & 8266.71 & 9446.11 & 9924.58 \\
\hline Makassar & 6706.13 & 7501.46 & 7565.25 & 7690.31 & 9040.99 & 10666.58 \\
\hline Mamuju & 7613.73 & 7489.85 & 7876.03 & 8107.55 & 8826.79 & 10773.81 \\
\hline Kendari & 6889.85 & 8186.44 & 8283.12 & 8446.03 & 9937.78 & 9551.98 \\
\hline Ambon & 8394.32 & 8981.29 & 9381.29 & 10292.05 & 11440.15 & 11818.78 \\
\hline Ternate & 8785.25 & 9462.62 & 9757 & 10447.98 & 11727.36 & 12030.75 \\
\hline Jayapura & 7551.39 & 10205.05 & 10325.14 & 11295.57 & 12393.81 & 12376.07 \\
\hline Manokwari & 9284.97 & 9137.30 & 10013.37 & 10686.52 & 11188.78 & 12965.26 \\
\hline
\end{tabular}

\section{Results and Discussion}

\subsection{Input and Target}

Rice retail price data in traditional markets is then processed using the backpropogation method. So that the data can be recognized by artificial neural networks, then the data must be represented in numerical form between $0-1$, this is because the network uses the activation function of binary sigmoid (logsig) which has a range of values $0-1$.

\subsection{Input Variable}

Variables are needed as input. In this case the data was obtained from the Badan Pusat Statistic with the subject of retail prices of rice in traditional markets (20112016). The data is divided into 2 parts, namely: Training data (2011-2013) and testing data (2014-2016).

\subsection{Target Variable}

The target variable used in the prediction of the retail price of rice on the traditional market includes: the retail price of rice.

\subsection{Output Variable}

The expected outcome at this stage is to form the best architectural model for predicting retail prices of rice in traditional markets. The test results are as follows:

a) The output of this prediction is the best architectural pattern in predicting the retail price of rice in traditional markets by looking at minimum errors.

b) Training and testing output categorization is the minimum error level of the target as shown in the following table: 
Table 2. Category Data

\begin{tabular}{|c|c|c|}
\hline No & Information & Error Minimum \\
\hline 1 & True & 0.09 between 0.001 and $-(0.05$ between 0.001$)$ \\
\hline 2 & False & $>0.09$ and $>(-0.09)$ \\
\hline
\end{tabular}

\subsection{Data processing}

Data processing is done with the help of the Matlab 6.1 application. The data used is the retail price of rice in the traditional market in 2011-2016. The data is divided into 2 parts, including: Training data (2011-2013) and testing data (20142016) as follows:

a) Training Data Input (X): Retail price of rice (2011-2012) - 33 provinces Output (Y): Rice retail prices for 2013 - 33 provinces

b) Testing Data Input (X): Retail price of rice (2011-2012) - 33 provinces Output (Y): Rice retail prices for 2013 - 33 provinces

The data is converted to $0-1$ because the activation function used is sigmoid biner (logsig). The following is the result of data conversion:

Table 3. Training data (Conversion)

\begin{tabular}{|r|l|c|c|c|}
\hline No & \multicolumn{1}{|c|}{ City } & $\mathbf{X 1}$ & $\mathbf{X 2}$ & $\mathbf{Y}$ \\
\cline { 3 - 5 } & & $\mathbf{2 0 1 1}$ & $\mathbf{2 0 1 2}$ & $\mathbf{2 0 1 3}$ \\
\hline 1 & Banda Aceh & 0,2704 & 0,3052 & 0,3508 \\
\hline 2 & Medan & 0,2197 & 0,3048 & 0,3602 \\
\hline 3 & Padang & 0,4288 & 0,4038 & 0,3978 \\
\hline 4 & Pekanbaru & 0,4019 & 0,4019 & 0,4296 \\
\hline 5 & Tanjung Pinang & 0,2494 & 0,4199 & 0,4719 \\
\hline 6 & Jambi & 0,2105 & 0,3153 & 0,3590 \\
\hline 7 & Palembang & 0,2117 & 0,2859 & 0,3121 \\
\hline 8 & Pangkal Pinang & 0,2140 & 0,3336 & 0,3718 \\
\hline 9 & Bengkulu & 0,2032 & 0,2577 & 0,2854 \\
\hline 10 & Bandar Lampung & 0,4965 & 0,3197 & 0,3410 \\
\hline 11 & Jakarta & 0,4338 & 0,3471 & 0,3870 \\
\hline 12 & Bandung & 0,2113 & 0,2858 & 0,3019 \\
\hline 13 & Serang & 0,2232 & 0,2180 & 0,2396 \\
\hline 14 & Semarang & 0,1670 & 0,2850 & 0,3233 \\
\hline 15 & Yogyakarta & 0,2268 & 0,2369 & 0,2836 \\
\hline 16 & Surabaya & 0,1000 & 0,2789 & 0,3236 \\
\hline 17 & Denpasar & 0,2787 & 0,3092 & 0,3478 \\
\hline 18 & Mataram & 0,1113 & 0,2176 & 0,2246 \\
\hline 19 & Kupang & 0,2520 & 0,2887 & 0,3359 \\
\hline 20 & Pontianak & 0,3548 & 0,4240 & 0,4724 \\
\hline 21 & Palangkaraya & 0,5264 & 0,5384 & 0,5128 \\
\hline 22 & Banjarmasin & 0,3769 & 0,4530 & 0,4368 \\
\hline 23 & Samarinda & 0,2518 & 0,3487 & 0,3982 \\
\hline 24 & Manado & 0,2150 & 0,3149 & 0,3339 \\
\hline 25 & Gorontalo & 0,1506 & 0,2694 & 0,2850 \\
\hline 26 & Palu & 0,1009 & 0,2423 & 0,2414 \\
\hline 27 & Makassar & 0,1206 & 0,1979 & 0,2041 \\
\hline 28 & Mamuju & 0,2088 & 0,1968 & 0,2343 \\
\hline 29 & Kendari & 0,1385 & 0,2645 & 0,2738 \\
\hline 30 & Ambon & 0,2847 & 0,3417 & 0,3805 \\
\hline 31 & Ternate & 0,3226 & 0,3884 & 0,4170 \\
\hline 32 & Jayapura & 0,2028 & 0,4606 & 0,4722 \\
\hline 33 & Manokwari & 0,3712 & 0,3568 & 0,4420 \\
\hline & & & & \\
\hline
\end{tabular}

Table 4. Testing data (Conversion)

\begin{tabular}{|r|l|c|c|c|}
\hline No & \multicolumn{1}{|c|}{ City } & X1 & $\mathbf{X 2}$ & Y \\
\cline { 3 - 5 } & & $\mathbf{2 0 1 4}$ & $\mathbf{2 0 1 5}$ & $\mathbf{2 0 1 6}$ \\
\hline 1 & Banda Aceh & 0,3756 & 0,4150 & 0,4644 \\
\hline 2 & Medan & 0,3993 & 0,4549 & 0,4939 \\
\hline 3 & Padang & 0,6070 & 0,6600 & 0,7117 \\
\hline 4 & Pekanbaru & 0,5545 & 0,6070 & 0,6613 \\
\hline 5 & Tanjung Pinang & 0,5733 & 0,6763 & 0,4964 \\
\hline 6 & Jambi & 0,4099 & 0,4733 & 0,4061 \\
\hline 7 & Palembang & 0,3315 & 0,4061 & 0,4767 \\
\hline 8 & Pangkal Pinang & 0,3949 & 0,5137 & 0,4374 \\
\hline 9 & Bengkulu & 0,4111 & 0,4815 & 0,5783 \\
\hline 10 & Bandar Lampung & 0,4229 & 0,4601 & 0,8067 \\
\hline 11 & Jakarta & 0,4433 & 0,6090 & 0,6752 \\
\hline 12 & Bandung & 0,3453 & 0,5082 & 0,5603 \\
\hline 13 & Serang & 0,2610 & 0,3582 & 0,4775 \\
\hline 14 & Semarang & 0,3617 & 0,4312 & 0,4283 \\
\hline 15 & Yogyakarta & 0,3495 & 0,4185 & 0,4649 \\
\hline 16 & Surabaya & 0,3639 & 0,4535 & 0,3973 \\
\hline 17 & Denpasar & 0,3742 & 0,4774 & 0,4971 \\
\hline 18 & Mataram & 0,3024 & 0,4026 & 0,4135 \\
\hline 19 & Kupang & 0,3559 & 0,4406 & 0,5461 \\
\hline 20 & Pontianak & 0,5198 & 0,6362 & 0,6813 \\
\hline 21 & Palangkaraya & 0,6759 & 0,9000 & 0,8112 \\
\hline 22 & Banjarmasin & 0,5643 & 0,6868 & 0,7235 \\
\hline 23 & Samarinda & 0,5464 & 0,5795 & 0,5619 \\
\hline 24 & Manado & 0,3652 & 0,4863 & 0,6025 \\
\hline 25 & Gorontalo & 0,3066 & 0,3787 & 0,4755 \\
\hline 26 & Palu & 0,2723 & 0,3868 & 0,4333 \\
\hline 27 & Makassar & 0,2163 & 0,3475 & 0,5054 \\
\hline 28 & Mamuju & 0,2568 & 0,3267 & 0,5158 \\
\hline 29 & Kendari & 0,2897 & 0,4346 & 0,3971 \\
\hline 30 & Ambon & 0,4690 & 0,5806 & 0,6174 \\
\hline 31 & Ternate & 0,4842 & 0,6085 & 0,6380 \\
\hline 32 & Jayapura & 0,5665 & 0,6732 & 0,6715 \\
\hline 33 & Manokwari & 0,5074 & 0,5562 & 0,7288 \\
\hline
\end{tabular}


Based on the discussion of the introduction to using code in Matlab 6.1 software, the following optimization parameters are used to predict the retail price of rice in traditional markets by improvising the learning rate:

Table 5. Optimization of Backpropagation Parameters

\begin{tabular}{|l|l|}
\hline \multicolumn{2}{|c|}{ Optimization } \\
\hline Dataset & Rice retail prices (33 data \\
\hline Distribution of Dataset & $\begin{array}{l}\text { Training (2011-2013) } \\
\text { Testing (2014-2016) }\end{array}$ \\
\hline \multirow{3}{*}{ Number of layers } & $\begin{array}{l}1 \text { input layer } \\
1 \text { hidden layer } \\
1 \text { output layer }\end{array}$ \\
\hline \multirow{2}{*}{ Neuron } & $\begin{array}{l}\text { The number of neurons in the input } \\
\text { and hidden layer according to number } \\
\text { of dataset inputs with } \\
\text { one neuron in the output layer } \\
\text { Neurons: } 10,15\end{array}$ \\
\hline Learning rate & 0,$1 ; 0,5 ; 0,9$ \\
\hline Target error & 0,09 between 0,001 \\
\hline
\end{tabular}

\subsection{Architectural Model Training and Testing Results 2-10-1 ( $\operatorname{Lr}=0,1 ; 0,5 ; 0,9)$}

The following are the complete results of training and testing of architectural models 2-10-1 (LR: 0.1;0.5; 0.9) in graphical form (epoch, MSE Training, MSE Training, Accuracy).

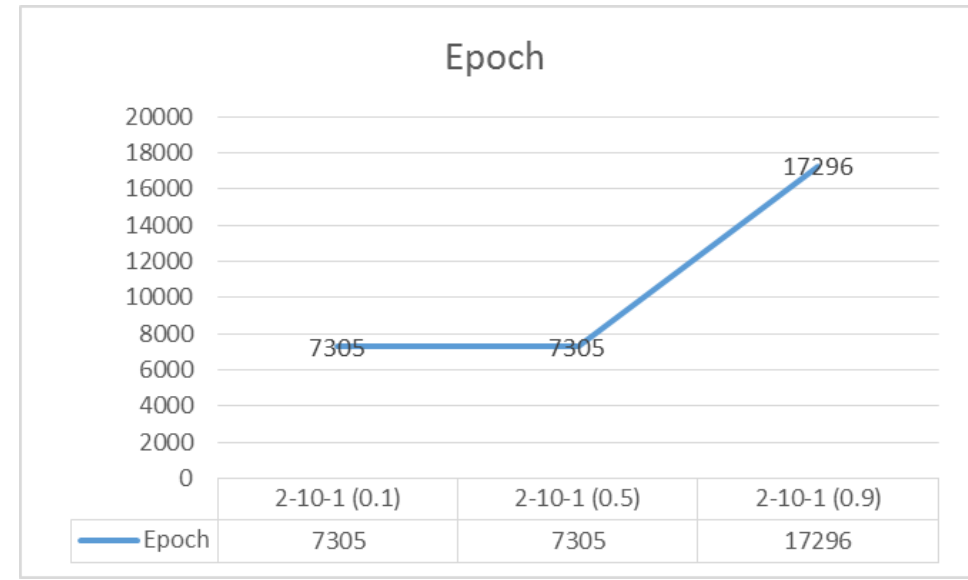

Figure 3. Comparison based on epoch

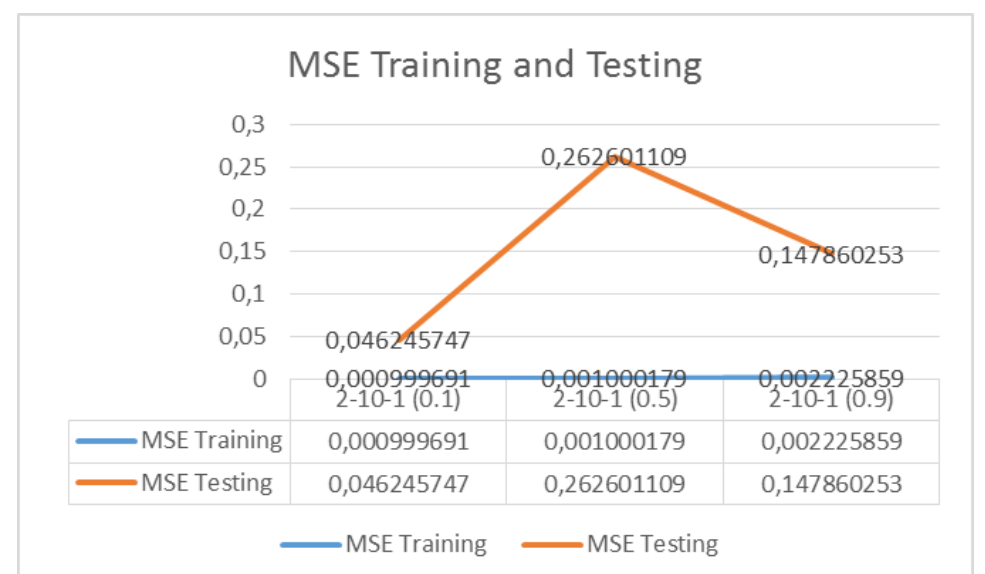

Figure 4. Comparison based on MSE training \& Testing 


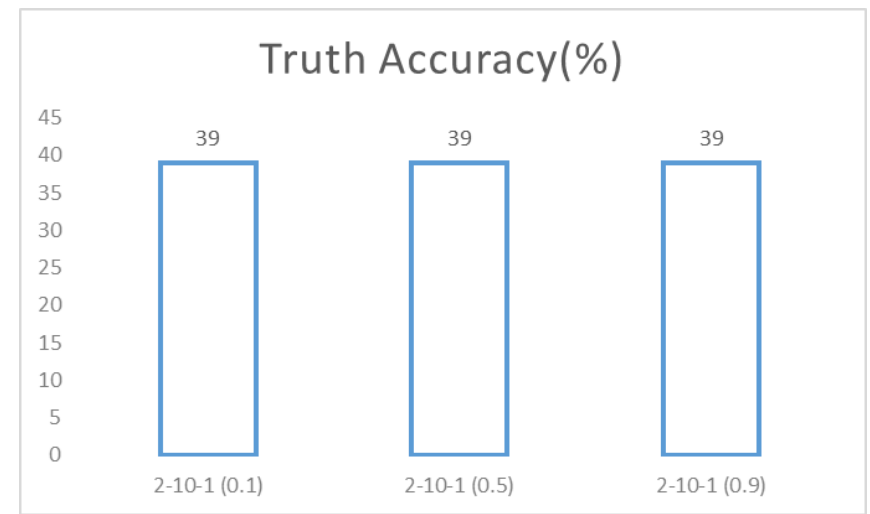

Figure 5. Comparison based on Accuracy

\subsection{Architectural Model Training and Testing Results 2-15-1 ( $\mathrm{Lr}=0,1 ; 0,5 ; 0,9)$}

The following are the complete results of training and testing of architectural models 2-15-1 (LR: 0.1;0.5; 0.9) in graphical form (epoch, MSE Training, MSE Training, Accuracy)

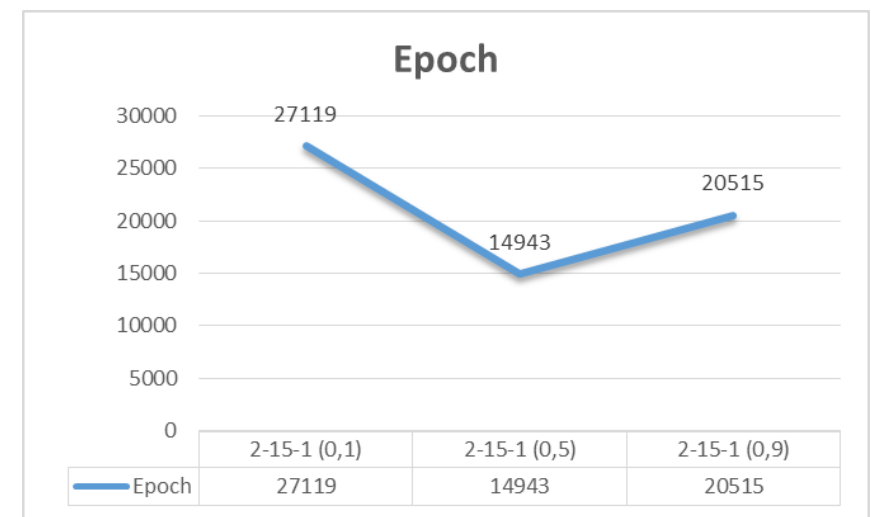

Figure 6. Comparison based on epoch

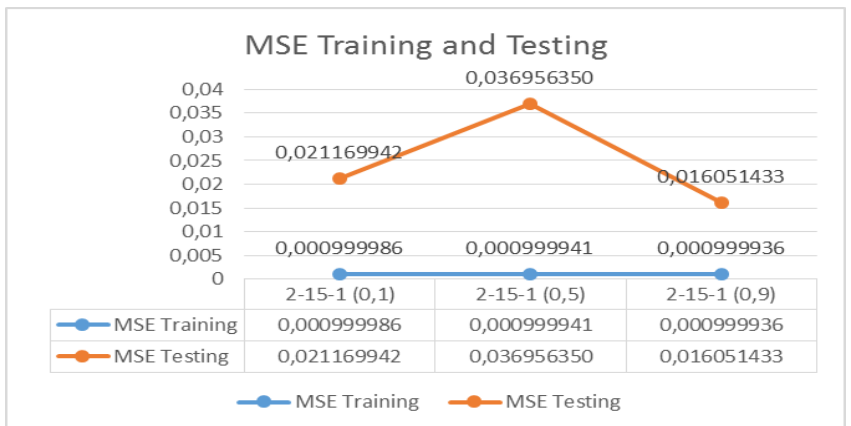

Figure 7. Comparison based on MSE training \& Testing 


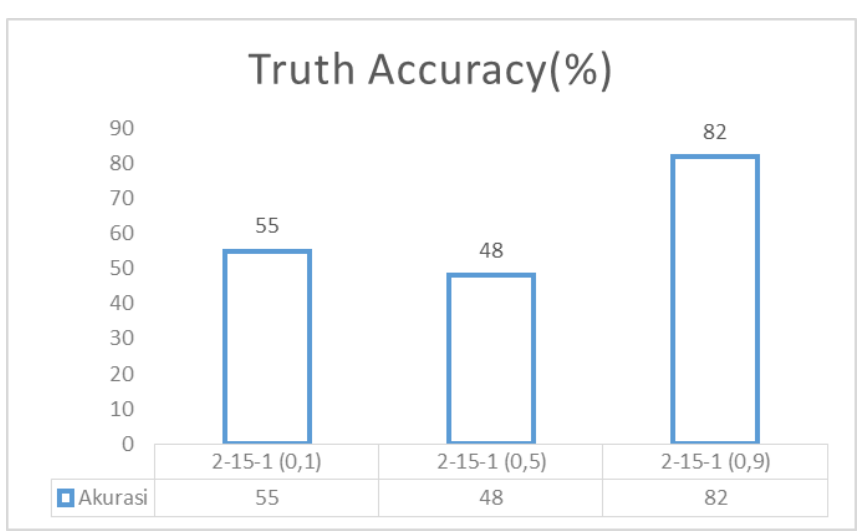

Figure 8. Comparison based on Accuracy

\subsection{Selection of the best ANN architectural model}

The selection of the best architecture in predicting retail prices of rice in traditional markets by improvising the learning rate using 2 models (2-10-1 and 215-1) using the Matlab 6.1 application software has different results both in terms of epoch, accuracy, MSE training and MSE testing. From these 2 models, improvised learning rate was carried out at LR: $0.1 ; 0.5$ and 0.9 . The following is a complete recapitulation in the following table:

Table 6. Recapitulation of Architectural Models

\begin{tabular}{|l|l|r|r|r|r|}
\hline Architecture & LR & Epoch & MSE Training & MSE Testing & Accuracy \\
\hline $2-10-1$ & 0.1 & 7305 & 0,000999691 & 0,046245747 & $39 \%$ \\
\hline $2-10-1$ & 0.5 & 7305 & 0,001000179 & 0,262601109 & $39 \%$ \\
\hline $2-10-1$ & 0.9 & 17296 & 0,002225859 & 0,147860253 & $39 \%$ \\
\hline $2-15-1$ & 0.1 & 27119 & 0,000999986 & 0,021169942 & $55 \%$ \\
\hline $2-15-1$ & 0.5 & 14943 & 0,000999941 & 0,036956350 & $48 \%$ \\
\hline $2-15-1$ & 0.9 & 20515 & 0,000999936 & 0,016051433 & $82 \%$ \\
\hline
\end{tabular}

Based on the table, the selection of the best architectural model is 2-15-1 with an accuracy rate of 82\%, MSE Training 0,000999936, MSE Testing 0.016051433 and Epoch 20515. In this case increasing accuracy for testing with improvised learning rate can be done for cases Predicted retail price of rice in traditional markets.

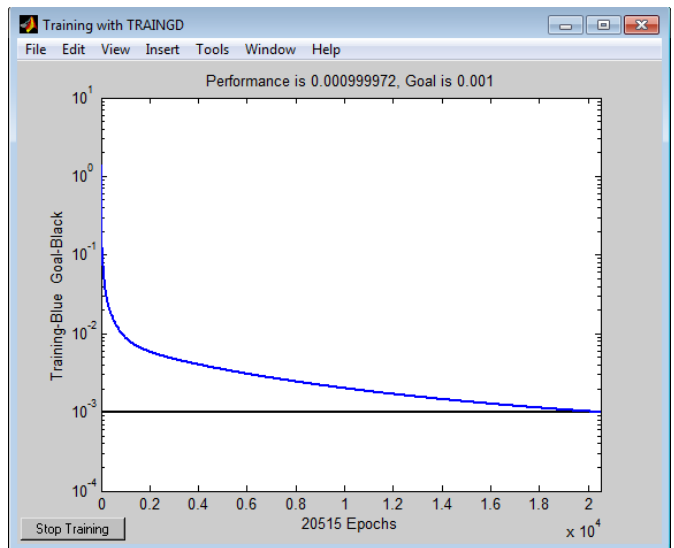

Figure 9. Architecture 2-15-1 achieving Goal (LR: 0.9)

\section{Conclusion}

The results of these studies can be concluded:

a) Artificial neural networks with backpropogation methods can be applied to predict the retail price of rice in traditional markets by improvising the learning 
rate. Data was obtained from the Central Statistics Agency (BPS) in 33 provinces in Indonesia for the retail price of rice in traditional markets (Rupiah / Kg) for the past 6 years (2011-2016). By improvising the learning rate using 2 models including: $2-10-1$ and $2-15-1(\operatorname{Lr}: 0.1 ; 0.5 ; 0.9)$ the best architectural model is obtained 2-15-1 (Lr: 0.9) with an accuracy rate of 82\%, MSE Training 0,000999936, MSE Testing 0.016051433 and Epoch 20515.

b) From a series of model trials, adding learning case predictions of retail prices of rice in traditional markets with backpropogation has increased the value of truth accuracy

\section{References}

[1] A. P. Windarto, "Penerapan Datamining Pada Ekspor Buah-Buahan Menurut Negara Tujuan Menggunakan K-Means Clustering Method," Techno.Com, vol. 16, no. 4, pp. 348-357, 2017.

[2] A. P. Windarto, "Implementation of Data Mining on Rice Imports by Major Country of Origin Using Algorithm Using K-Means Clustering Method," Int. J. Artif. Intell. Res., vol. 1, no. 2, pp. 26-33, 2017.

[3] A. P. Windarto, "Penerapan Data Mining Pada Ekspor Buah-Buahan Menurut Negara Tujuan Menggunakan K-Means Clustering," Techno.COM, vol. 16, no. 4, pp. 348-357, 2017.

[4] D. Nabila Batubara, "Analisis Metode K-MEANS Pada Pengelompokan Keberadaan Area Resapan Air Menurut Provinsi," Semin. Nas. Sains Teknol. Inf., pp. $345-349$, Jul. 2019.

[5] C. Astria, "Metode K-Means Pada Pengelompokan Wilayah Pendistribusian Listrik," Semin. Nas. Sains Teknol. Inf., pp. 306 - 312, Jul. 2019.

[6] T. Budiharjo, Soemartono, T., Windarto, A.P., Herawan, "Predicting tuition fee payment problem using backpropagation neural network model," Int. J. Adv. Sci. Technol., 2018.

[7] T. Budiharjo, Soemartono, T., Windarto, A.P., Herawan, "Predicting school participation in indonesia using back-propagation algorithm model," Int. J. Control Autom., 2018.

[8] A. P. Windarto, M. R. Lubis, and Solikhun, "IMPLEMENTASI JST PADA PREDIKSI TOTAL LABA RUGI KOMPREHENSIF BANK UMUM KONVENSIONAL DENGAN BACKPROPAGATION," J. Teknol. Inf. dan Ilmu Komput., vol. 5, no. 4, pp. 411-418, 2018.

[9] A. P. Windarto, M. R. Lubis, and Solikhun, "MODEL ARSITEKTUR NEURAL NETWORK DENGAN BACKPROPOGATION PADA PREDIKSI TOTAL LABA RUGI KOMPREHENSIF BANK UMUM KONVENSIONAL," Kumpul. J. Ilmu Komput., vol. 5, no. 2, pp. 147-158, 2018.

[10] A. P. Windarto, L. S. Dewi, and D. Hartama, "Implementation of Artificial Intelligence in Predicting the Value of Indonesian Oil and Gas Exports With BP Algorithm," Int. J. Recent Trends Eng. Res., vol. 3, no. 10, pp. 1-12, 2017.

[11] Sumijan, A. P. Windarto, A. Muhammad, and Budiharjo, "Implementation of Neural Networks in Predicting the Understanding Level of Students Subject," Int. J. Softw. Eng. Its Appl., vol. 10, no. 10, pp. 189-204, 2016.

[12] S. Putra Siregar and A. Wanto, "Analysis Accuracy of Artificial Neural Network Using Backpropagation Algorithm In Predicting Process (Forecasting)," Int. J. Inf. Syst. Technol., vol. 1, no. 1, pp. 34-42, 2017.

[13] Solikhun, A. P. Windarto, Handrizal, and M.Fauzan, "Jaringan Saraf Tiruan Dalam Memprediksi Sukuk Negara Ritel Berdasarkan Kelompok Profesi Dengan Backpropogation Dalam Mendorong Laju Pertumbuhan Ekonomi," Kumpul. J. Ilmu Komput., vol. 4, no. 2, pp. 184-197, 2017.

[14] B. Febriadi, Z. Zamzami, Y. Yunefri, and A. Wanto, "Bipolar function in backpropagation algorithm in predicting Indonesia's coal exports by major 
destination countries," IOP Conf. Ser. Mater. Sci. Eng., vol. 420, no. 12089, pp. 19, 2018.

[15] B. Fachri, A. P. Windarto, and I. Parinduri, "Penerapan Backpropagation dan Analisis Sensitivitas pada Prediksi Indikator Terpenting Perusahaan Listrik," $J$. Edukasi dan Penelit. Inform., vol. 5, no. 2, pp. 202-208, 2019.

\section{Authors}

\section{$1^{\text {st }}$ Author}

Erwin Binsar Hamonangan Ompusunggu

STIKOM Tunas Bangsa, Pematangsiantar, North Sumatra 